is stated - in quite another connection - to have been noted for his "veracity;" and this is quite borne out, in this instance, by the evidence of two contemporary writers and the minute-book of the College of Physicians.

That these skiffs were "kayaks," and that their occupants were practically Eskimoes, is what I have never seen called in question. The tirst writer (Wallace) conjectures that they actually were Eskimoes from Davis Straits. This also is the explanation offered by some critics, whose preconceived notions prevent them from entertaining the idea that certain European castes, within comparatively recent times, may have been (ethnologically) Eskimoes. Wallace's son, editing his father's book in 1693, thinks it "a little unaccountable how these Finn-men should come on this coast," from so great a distance as Greenland. And Brand (1701), who calls them also "Finland-men," regards it as "strange" and " wonderful" that they should come even from Finland,- - assumed by him to be their home. Orkney tradition, which styles them "Finns" and "Fin-folk," connects them with a certain island in Orkney, with Shetland, with Norway, with the Faroe Islands, and even with Iceland.

It is perhaps within the bounds of possibility that Greenland "kayakkers" made their way to the Orkneys, via Iceland, the Faroes, and Shetland, about the year 1680. But this assumption seems to me so unreasonable that I cannot entertain it. Were the "Finn-men" of 1701 the immigrants of 1682 , and had they been living in retirement about the Orkneys all that time? Or, when pursued by the Orkney fishermen, as they often were, did they retreat on each occasion to Greenland? But it is futile to suggest questions such as these. It is much more reasonable to assume that the stories about "Finns" and "Fin-folk" (though blended in modern times with impossible stories about seals) hare an actual historical basis, and relate to a people whose home was in Europe and not in America.

I dare not trespass further upon your valuable space, or I would say more with regard to the various points selected for criticism. I shall only add that the reference to the Delaware Finns of the seventeenth century is not my ow $\mathrm{n}$, but is quoted (at $\mathrm{p}$. 36); that "Finn" and "Lapp" were once used interchangeably, though now distinct; and that, according to C. F. Keary ("The Vikings," p 157), the Scandinavian peninsula, almost as far south as the 60th parallel, "was Lapp or Finnish territory" in the ninth century, which allows of possible surviving remnants at a much later date in that region, - not to speak of the British Isles.

Edinburgh, March \%.

David MacRitchie.

\section{A Possible Source of Confusion as to the Origin and Character of Certain Shells.}

IT is quite possible that in studying the fossils of a single stratum of rock or even so small a fragment as a hand specimen, one may find examples over which he pauses. Wide divergences may exist between shells that lie side by side. They have evidently been deposited from the same waters. Apparently, they have flourished under like surroundings of depth and character of water. Yet one example may bear traits of fresh-water origin, while another may be as distinctly of marine growth.

The key to the anomoly may probably be found in what is now going on along our lake shores. Take as illustration the intermingling of marine and lacustrine forms on the borders of Lake Champlain. In favorable places there are found closely packed accumulations of unios and related shells. The waves that hare brought these to the shore have at the same time been gnawing at the banks of clay of the Champlain epoch. In these are imbedded saxicava and associated forms. The clay is worked over by the waters; the finer particles drift out into the lake, the coarser with the liberated shells sink down among the unios. So a firm stratum is made from forms now existing in the waters and those that long ago flourished there. These deposits await the phenomena that have consolidated like ones along shores in older geological time, after which shells of different origin and character may be broken from the same rock.

\section{BOOK-REVIEWS.}

A Microscopic Study of Changes due to Functional Activity of Nerve Cells. Reprinted from the Journal of Morphology. By C. F. Hodae. Boston, Ginn \& Co.

THE present investigation is the beginning of a new line of research, and Professor Hodge is to be congratulated on his successful pioneer work. It consists of an account of a long series of patient observations made upon the spinal nerve-cells of the frog and the cat under the influence of stimulation through the spinal nerres. The general conclusion is that stimulation. of the nerve-cell produces changes, in the structure of the cell, which are visible to the microscope. The most noticeable and tangible of these changes is the shrinking of the nucleus. This shrinking of the nucleus was seen in all of the experiments described, and that it was not a pathological change was proved by the fact that a rest after the stimulation caused in a few hours a recovery of the nucleus to its normal size. Perhaps the most interesting results of the whole series of experiments was a comparison of the nerve-cells of the spinal cord and brain in animals killed in the morning after a night's rest, and similar animals killed at night after a day's activity. In every case a very striking difference in the microscopic appearance of the nerve cells was manifest. The whole line of work is extremely suggestive and very promising of important results in the future.

The Naturalist on the River Amazons. By HENRY WALTER BATEs. With a memoir of the author by Edward Clodd.

Reprint of the unabridged edition. New York, D. Appleton

\& Co. 395 p. Map. $8^{\circ}$.

Among the thousands of volumes that crowd the shelves of our great libraries there are few that have ever reached the honor of a second edition. Fewer still attain a third and fourth, and rare indeed is the instance of one that, decade after decade, and generation after generation, continues to delight the human soul. The vast majority of printed books are as ephemeral as the Mayfly, born and dying in the same hour, read and forgotten as we read and forget the gossip of a Sunday paper. Those volumes that, no matter how often they are reprinted, are always fresh and new, and which give delight to the younger as they did to the older generation, we christen "classics." Some have come to us from ancient Greece and Rome : others from the Middle Ages: some from more recent days. In no single century, however, are there more than a small number that ever reach the pinnacle of public approval and become designated as classics. The more books there are the greater the numbers that are cast aside; so that in our time, when thousands of volumes are being poured from the press year after year, the chances that any one will be successful in achieving the highest honor are slight indeed. A book must possess more than usual worth: give to the jaded world some new ideas, and be couched in language to be read by old and young with equal pleasure. Books like the one at present under review belong to that category which includes such volumes as White's Selbourne, Darwin's Voyage, and Wallace's Malay Archipelago, - books which have fulfilled the requirements of classics, and which bave been accorded that title by a grateful public.

No one can err, we believe, in placing Bates's "Naturalist on the River Amazons" among the foremost books of travel of this age; and no one who has read it, but recalls its graphic pages with delight. Pages that bring to those who have not seen with material eyes the wonders of the tropic zone, images of delight; and that recall to those who have seen these wonders visions of never-to-be-forgotten pleasure. It is said of the ornithologist Gould, who had long desired to visit the forests of the Amazons, that, meeting Bates after the appearance of his book, he exclaimed: "Bates, I have read your book; I have seen the Amazons!" It is now thirty years since the first edition appeared. Since then many others have been printed, mainly based, however, upon the second edition. This, upon the advice of his publisher and to his lasting regret, Bates abridged to a considerable extent. The public is, therefore, most grateful to have reproduced, as in the beautiful volume before us, the unabridged words of the author, 
written when time had not dimmed nor distance distorted the vividness of the images he depicts. But the volume also contains a sketch of the life of Mr. Bates, with extracts from his journals and letters, together with an abridgment of the celebrated article on mimicry in butterflies, which placed its author at once in the front rank of philosophical naturalists. The book, therefore, becomes practically a new one, which every lover of such literature should not fail to possess.

The life of Mr. Bates, aside from his travels on the Amazons, was an uneventful one. He was born in Leicester, on Feb. 8, 1825 , and was apprenticed at the age of 13 to a hosiery manufacturer. He inherited from his mother a tendency toward dyspepsia, and so was always far from strong, but he early manifested a love for natural history, and spent all his spare time hunting butterflies and beetles. He began to write out his notes at an early age, and before he was 20 years old he had published some of his observations. It was while at Leicester that he made the acquaintance of Wallace, and the two friends went, in 1848, to the Amazons. His companion remained four years, but Bates himself stajed for seven years longer, and returned to England in 1859 , with about 15,000 species, 8,000 of which were new to science, and with a wealth of observations that occupied his pen for many years.

Bates was the first to point out the curious fact of mimetic analogies between various species of butterflies, and to suggest that the cause of the mimicry was natural selection. He also suggested that the reason for the mimicry lay in the unpalatableness of the mimicked species, so that the mimickers, although themselves edible, escaped their enemies by taking on the form and coloration of the species that birds would not eat. An abstract of this paper, with a colored plate, is given in Dr. Clodd's memoir.

Among the more interesting portions of this part of the volume are a few extracts from Bates's journal. It is to be regretted that there are not more. In the following he records some of his impressions of Lyell.

"Sir Charles Lyell has the appearance of a fidgety man not well at ease with himself. He is very greedy of fame, and proud of his aristocratic friends and acquaintances. He does not seem to be a very ready man; his learning does not appear to be at his fingers' ends; so that when a subject is suddenly presented to him he has difficulty in collecting his scattered thoughts and bringing forth what he knows upon it. But then he is getting an old man now. Mr. Davidson told me he was a very hesitating writer, and re-wrote every sentence three or four times on the average. . . . But, like a well-bred gentleman, Sir Charles can become very sociable, and evidently likes a good dinner with brilliant conversation: Darwin says he likes to hear himself talk. At the Geological Club . . . he made me laugh by retailing a very good thing. The conversation ran on the comparative merits of the scientific hypothesis of the origin of man and the biblical man. 'Why,' says he, 'the question resolves itself into few words: Is man modified mud, or modified monkey?",

It was due to the urgency of Darwin that Bates began and continued to write his travels; and on the appearance of the book in 1863 it met with cordial praise from all quarters. His style is direct and concise. While many writers would have given a long account of the outward voyage from England, Bates disposes of it in three lines, and plunges almost at once into the luxuriant forests that were to be his home for eleven long years. His first walk in the forest was taken with Wallace on the day of their arrival at Pará, and a part of it is thus described :-

"As we continued our walk the brief twilight commenced, and the sounds of multifarious life came from the vegetation around. The whirring of cicadas, the shrill stridulation of a vast number and variety of field-crickets and grasshoppers, each species sounding its peculiar note; the plaintive hootings of tree-frogs, - all blended together in one continuous ringing sound, - the audible expression of the teeming profusion of nature. As night came on, many species of frogs and toads in the marshy places joined in the chorus; their croaking and drumming, far louder than anything $I$ had before heard in the same line, being added to the other noises, created an almost deafening din. This uproar of life, I afterwards found, never wholly ceased, night or das; in course of time I became, like other residents, accustomed to it. It is, however, one of the peculiarities of a tropical - at least a Brazilian - climate which is most likely to surprise a stranger. After my return to England, the death-like stillness of days in the country appeared to me as strange as the ringing uproar did on my first arrival at Pará."

The fact of a struggle for existence among animals is generally recognized by all, but the same struggle among plants is not so easily observed. In the luxuriant forests of the tropics the fact is forced upon all observers, and Bates gires a striking example of it. A parasitic tree occurs very commonly near Pará, which bas received the appropriate name of the Murderer Liana or Sipó. It is described and the fact commented upon as follows: "It. springs up close to the tree on which it intends to fix itself. and the wood of its stem grows by spreading itself like a plastic mould. over one side of the trunk of its supporter. It then puts forth from each side an arm-like branch, which grows rapidly, and looks as though a stream of sap were flowing and bardening as it went. This adheres closely to the trunk of the victim, and the two arms meet on the opposite side and blend together. These arms are put forth at somewhat regular intervals in mounting upwards, and the victim, when its strangler is full-grown, becomes tightly clasped by a number of inflexible rings. These rings gradually grow larger as the murderer flourishes, rearing its crown of foliage to the sky, mingled with that of its neighbor, and in course of time they kill it by stopping the flow of its sap. The strange spectacle then remains of the selfish parasite clasping in its arms the lifeless and decaying body of its victim, which had been a belp to its own growth. Its ends have been served - it has flowered and fruited. reproduced and disseminated its kind; and now, when the dead trunk moulders away, its own end approaches; its support is gone, and itself also falls.

"The Murderer Sipó merely exhibits, in a more conspicuous manner than usual, the struggle which necessarily exists amongst vegetable forms in these crowded forests, where individual is competing with individual and species with species, all striving to reach light and air in order to unfold their leaves and perfect their organs of fructification. All species entail in their successful struggles the injury or destruction of many of their neighbors or supporters, but the process is not in others so speaking to the eye as it is in the case of the Matador. The efforts to spread their roots are as strenuous in some plants and trees as the struggle to mount upwards in others. From these apparent strivings result the buttressed stems, the dangling air-roots, and other similar pbenomena. The competition amongst organized beings has been prominently brought forth in Darwin's 'Origin of Species;' it is a fact which must be always kept in view in studying these subjects. It exists everywhere, in every zone, in both the animal and vegetable kingdoms. It is doubtless most severe, on the whole, in tropical countries, but its display in regetable forms in the forest is no exceptional phenomenon. It is only more conspicuously exhibited, owing perhaps to its affecting principally the vegetative organs, - root, stem, and leaf, - whose growth is also stimulated by the intense light, the warmth, and the humidity. The competition exists also in temperate countries, but it is there concealed under the external appearance of repose which vegetation wears. It affects, in this case, perhaps more the reproductive than the vegetative organs, especially the flowers, which it is probable are far more general decorations in the woodlands of high latitudes than in tropical forests."

It is as much in the reflections that the varied phenomena under observation give rise to as in the descriptive portions that the value and charm of the book lie. There is always something new. Now it is the colossal trees, then the wonderful profusion of insect life, or the graphic pictures of free life in the forest. Nothing is more striking than the difference between the fauna on the two banks of the great Amazons, and Bates refers to this in numerous places. So, too, the wonderful fact that certain insects, especially the butterflies, mimic others is of vast interest. Then the great variation presented by some forms of insects, so that at the two ends of a series we have what are commonly called distinct species, while there are intermediate forms presenting every gradation between them. Those naturalists who 
claim that species do not originate now in a state of nature, would certainly find it a difficult task to refute or explain on any but one hypotbesis the facts given by our author. One case in particular is of great interest. It would appear that two butterflies, species of Heliconius, are extremely abundant in the forests along the river. They inhabit, however, different sections of the country, one of which in moister than the other. One species occurs in the dry forests, the other in the moister ones. One species, $H$. melpomene, is black with a large crimson spot on its wings; the other is $H$. thelxiope, in which the wings are beautifully rayed with black and crimson and hare a number of brightyellow spots. Both have the same habits, and they have long been regarded as perfectly distinct species. We quote now $\mathrm{Mr}$. Bates's words: “There are, as might be supposed, districts of forest intermediate in character between the drier areas of Obydos, etc., and the moister tracts which compose the rest of the immense river valley. At two places in these intermediate districts, . . . most of the individuals of these Heliconii which occurred were transition forms between the two species. Already, at Obydos, $H$. melpomene showed some slight variation amongst its individuals in the direction of $H$. thelxiope, but not anything nearly approaching it. It might be said that these transition forms were hybrids, produced by the intercrossing of two originally distinct species; but the two come in contact in several places where these intermediate examples are unknown, and I never observed them to pair with each other. . . These hybrid-looking specimens are connected together by so complete a chain of gradations that it is difficult to separate them even into varieties, and they are incomparably more rare than the two extreme forms. They link together gradually the wide interval between the two species. One is driven to conclude, from these facts, that the two were originally one and the same; the mode in which they occur and their relative geographical positions being in favor of the supposition that $H$. thelixiope has been derived from $H$. melpomene. Both are, nevertheless, good and true species in all the essential characters of species; for, as already observed, they do not pair together when existing side by side, nor is there any appearance of reversion to an original common form under the same circumstances."

We have already so far overstepped our space that we must reluctantly refrain from quoting further. We would, however, call particular attention to the account given of Termites on pages 209-214; that on Fire Ants on page 227; on Monkeys on pages 331-345; and on the general features of ant life on pages 355-363. The remarks upon floating pumice on pages 263-264 are well worthy the consideration of students of geographical distribution, and those on page 169 are commended to the student of comparative philology, as indicating a method of the formation of dialects among savage tribes.

One word more and we have done; for even at the risk of tiring the patient reader we add one more quotation. After a life of eleven years spent in the Amazonian forests, certainly Bates was well qualified to judge between that life and civilized man's. He had formed a love for the country, and he took leave of it with regret. The desire, however, of once again seeing his parents and of enjoying the pleasures of intellectual society drew him from this "Naturalists' Paradise." "During this last night on the Pará River," he says, " a crowd of unusual thoughts occupied my mind. Recollections of English climate, scenery, and modes of life came to me with a vividness I had never before experienced during the eleven years of my absence. Pictures of startling clearness rose up of the gloomy winters, the long, gray twilights, murky atmosphere, elongated shadows, chilly springs, and sloppy summers; of factory chimneys and crowds of grimy operatives, rung to work in early morning by factory bells; of union workhouses. confined rooms, artificial cares and slavish conventionalities. To live again amidst these dull scenes $I$ was quitting a country of perpetual summer, where my life had been spent, like that of three-fourths of the people, in gypsy fashion, on the endless streams or in the boundless forests. I was leaving the equator, where the well-balanced forces of nature maintained a land surface and climate that seemed to be typical of mundane order and beauty, to sail towards the North Pole, where lay my home, under crepuscular skies, somewhere about fifty-two degrees of latitude. It was natural to feel a little dismayed at so great a change; but now, after three years of renewed experience of England, I find how incomparably superior is civilized life, where feelings, tastes, and intellect find abundant nourishment, to the spiritual sterility of half-savage existence, even if it were passed in the Garden of Eden. What has struck me powerfully is the immeasurably greater diversity and interest of human character and social conditions in a single civilized nation than in equatorial South America, where three distinct races of man live together. The superiority of the bleak north to tropical regions, however, is only in its social aspect; for I hold to the opinion that, although bumanity can reach an advanced state of culture only by battling with the inclemencies of nature in high latitudes, it is under the equator alone that the perfect race of the future will attain to complete fruition of man's beautiful heritage, the earth."

JOSEPH F. JAMES

Text-Book of the Embryology of Man and of Mammals. By DR. Oscar Hertwig. Translated by Professor E. L. Mark. New York, Macmillan \& Co. $\$ \mathbf{\$ 5 . 2 5}$.

Professor Mark has done a great service to English science by translating this text-book of embryology. The appreciation of the book abroad is shown by the fact that the edition which is now translated is the third edition since its criginal publication in 1866, the third edition of the first part of the textbook being demanded before the second part was ready for publication. The valuable scientific researches of Hertwig are very well known by all naturalists, and his name alone is sufficient to indicate the reliability of the work in hand.

The title, "A Text-Book of Embryology of Man and Mammals," does not adequately express the scope of the book, for while it is in details largely confined to the study of mammals, there is so much of general embryology within its covers as to give it a value as a general text-book of vertebrate embryology. As such a text-book it is of the greatest value to a student, and it is safe to say that at the present time there is no text-book so well designed to give the student a general knowledge of vertebrate embryology as the present one.

The subjects treated comprise all matters of importance connected with invertebrate embryology. They are treated in a masterly style, and the facts and discussions are in all cases brought up to date. In the chapters on the sexual products and their fertilization may be found a summary of the essential facts of our present knowledge upon this important subject. The chapter on cleavage discusses the general matter of the segmentation of eggs, giving the various types of euch segmentation, their relations to each other and defining the terms used in descriptions in various text-books. The chapter on the gastrula is especially valuable, for it gives in a clear, logical, but concise manner, illustrated by valuable and intelligible drawings, our present ideas as to the application of the gastrula theory to the embry. ology of vertebrates. It is a subject which is always puzzling to the student of embryolog $\nabla$ to understand the gastrulation of the vertebrate egg, and Professor Hertwig has done very much toward making this difficult subject intelligible. Not the least valuable part of this section is an outline history of the gastrula theory, tracing our knowledge of embryology of the germ layers from its infancy to the present time. The gastrula theory is accepted by Professor Hertwig in its fullest sense. The chapter on the formation of the body cavity gives Professor Hertwig an opportunity of explaining clearly his "coelomthorie" which he does in a clear style, and the significance of which he makes plain by its bistorical consideration. In addition to the above, there are considered in the first part of the work the segmentation of the vertebrate embryo, the origin of connective tissues, the method of formation of the external form of the vertebrate body and a study of the fotal membranes of reptiles, birds, mammals, and man. In all of these sections the aim of Professor Hertwig is not only to give facts but to give a logical connective account of the significance of the facts and a logical understanding of the various phases in the development of the vertebrate body, and he has greatly added to the value of 